\title{
Effects of seedbed preparation and cattle trampling on bur- ial of grass seeds
}

\author{
VON K. WINKEL, BRUCE A. ROUNDY, AND DAVID K. BLOUGH
}

\begin{abstract}
Location of seeds in the seedbed may affect germination and seedling establishment of range grasses. Our objective was to determine the effects of trampling by livestock and mechanical seedbed preparation on burial of grass seed on a sandy loam seedbed. Plots were root plowed or ripped then broadcast seeded, or broadcast seeded then lightly or heavily trampled by cattle or land imprinted before summer rains. Seedbeds were sampled by extracting soil plugs with plastic vials, splitting the plugs, and determining seed location with a dissecting scope. Sampling occurred after treatment, after summer thunderstorms, and after seedling emergence. An average of $75,42,17$, and $7 \%$ of seeds found were buried immediately after heavy trampling, land imprinting, light trampling, and no disturbance, respectively. After summer thunderstorms an average of $78,72,63,40$, and $29 \%$ of seeds found were buried on plots root plowed or ripped, heavily trampled, imprinted, lightly trampled, and undisturbed, respectively. Although high percentages of seeds were buried on plots heavily trampled, imprinted, and root plowed or ripped, many of these seeds were too deep for seedling emergence. Smaller-seeded blue panic (Panticum antidotale) and the lovegrasses (Eragrostis lehmanniana Nees and Eragrostis lehmanniana Nees $X \mathbf{E}$. trichophera) were buried by treatment and rain better than sideoats grama [Bouteloua curtipendula (Michx) Torr.].
\end{abstract}

Key Words: seed location, seed depth, seedbed preparation, revegetation, root plowing, land imprinting, sideoats grama, blue panic, Lehmann lovegrass, Cochise lovegrass

Reasons for failure of some seedings on semiarid rangelands may include insufficient soil water and soil coverage of seeds, and unfavorable temperature (Vallentine 1989); lack of radicle entry (Campbell and Swain 1973, Sheldon 1974, and Cox and Martin 1984); ant, bird, and rodent predation (Howard 1950, Nelson et al. 1970); and excessive seed burial (Mutz and Scifres 1975).

Drilling is the preferred method for sowing seeds on most rangelands. Drilling distributes and covers seeds more uniformly and places seeds at a desired depth more accurately than broadcasting (Vallentine 1963, Jordan 1981). However, drilling is not always practical and broadcast seeding must be used on steep slopes and rough terrain.

Broadcast seeding of small-seeded species on prepared seedbeds before summer rains has produced similar seedling emergence as drilling in the southwestern United States (Cox et al. 1986). Chaining, ripping, plowing, and imprinting have all been used to help prepare seedbeds (Allison and Rechenthin 1956; Tiedemann and Schmutz 1966; Haferkamp 1987; and Clary 1988, 1989). It has been assumed that these treatments help to bury seeds. Livestock trampling following broadcast seeding has also been suggested as helping to bury seeds (Plummer 1955, Hormay 1970, Vallentine 1989, Pearson and Ison 1987). Little information is available on where

\footnotetext{
Authors are former graduate research associate and associate professor, School of Renewable Natural Resources, and assistant professor, Dept. of Agriculture Economics, University of Arizona, Tucson 85721. Winkel is currently scientist EG and G Energy Measurements, P.O. Box 1912 M/S P-03 Las Vegas, Nevada 89125.

The authors wish to thank John King for providing the study site, and Aurora Ortiz Lopez, Catherine Plume, and I. Bradford Sumrall for assistance in data collection.

Research was funded by USDA Rangeland Research Grants program. Published as Arizona Agricultural Experiment Station Paper 7187.

Manuscript accepted 12 May 1990.
}

trampling or mechanical seedbed preparation of rangeland soils places seeds in the seedbed.

Our objective was to determine the effects of cattle trampling, land imprinting, root plowing or ripping, and summer thunderstorms on location of broadcast grass seeds.

\section{Methods}

The study was conducted on the Anvil ranch, about $65 \mathrm{~km}$ southwest of Tucson, Ariz., in conjunction with a seedling establishment study. The soil at the site is a sandy loam (fine, mixed, thermic Ustollic Haplargids).

The experimental design of the study was a randomized block with 4 grass species $\times 5$ seedbed treatments applied to each of 3 blocks on each of 2 years (1987 and 1988).

Seedbed treatments applied to 6- by 6-m plots included light cattle trampling (approximately 10 hoofprints per $\mathrm{m}^{2}$ ), heavy cattle trampling ( 5 cattle herded inside the plot for 20 minutes to thoroughly disturb the upper $4 \mathrm{~cm}$ of soil), land imprinting, root plowing (1987) or ripping (1988), and no disturbance. Land imprinting consists of pulling water-filled metal cylinders with welded angle forms which imprint a furrow about 5-10-cm deep (Dixon and Simanton 1980).

Plots were seeded after root plowing or ripping, but were seeded prior to all other seedbed treatments. Two $1-\mathrm{m}^{2}$ subplots within each 6- by 6-m treatment plot were intensively broadcast seeded with 'Vaughn' sideoats grama (Bouteloua curtipendula (Michx.) Torr.), 'A-130' blue panic ( Panicum antidotale Retz.), 'A-68' Lehmann lovegrass (Eragrostis lehmanniana Nees), or Cochise lovegrass (Eragrostis lehmanniana Nees $\times E$. tricophera Coss and Dur.).

The volume of seeds of each species necessary to completely cover the soil surface of the $1-\mathrm{m}^{2}$ subplots with a single layer of seeds were determined. Seeds were evenly broadcast across the subplots by using a grid and seeding each of $16,1 / 16-\mathrm{m}^{2}$ areas. The soil surface was then protected with cotton cloth, the seedbed wetted, and $3.5-$ by $5.0-\mathrm{cm}$ soil plugs extracted with plastic vials. Samples were taken to the laboratory, split in half, and seeds were located with a dissecting microscope (Winkel and Roundy 1991a). Four samples were collected from each subplot for a total of 480 samples per sample period and 24 samples per treatment-species combination per sample period. Data were recorded as percent of seeds found at particular depths in the seedbed.

Seedbeds were sampled immediately after treatment application (1987 and 1988), a few weeks later after the first major thunderstorm (1987 and 1988), and after seedling emergence ( 1987 only for blue panic, Cochise and Lehmann lovegrass, and 1988 only for sideoats grama). Root-plowed or ripped plots were not sampled after treatment because of the heterogeneous nature of the seedbed, but were sampled after rain and seedling emergence. Seed distribution was sampled after a $20-\mathrm{mm}$ rain in 1987 and after a 35-mm rain in 1988.

Repeated measures analysis of variance was performed on the soil depth at which cumulative percentages of seeds were found, and p-values were adjusted with Greenhouse-Geisser statistics (Morrison 1976). This analysis was used to determine differences in seed distributions in the seedbed after treatment and after summer 


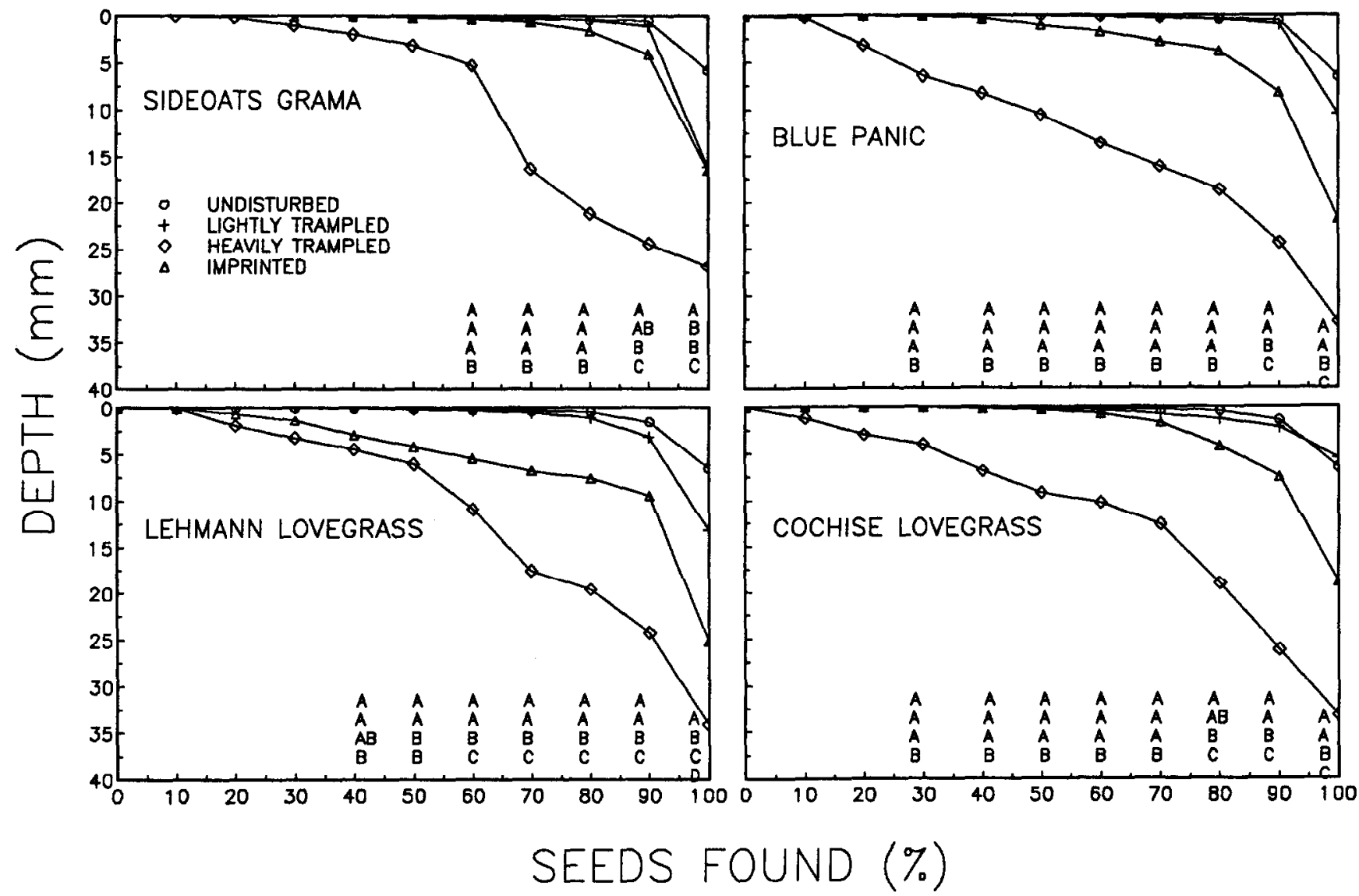

Fig. 1. Vertical distribution of broadcast sideoats grama, blue panic, and Cochise and Lehmann lovegrass seeds in a sandy loam soil immediately after seedbed treatment in 1988. Columns having the same letters are not significantly different $(P>0.05)$.

thunderstorms among years, species and treatments, as well as differences in depth of seedling emergence among species and treatments. The biological limit of each species was determined by plotting and regressing the cumulative percentage of seeds that produced emergent seedlings on seed depth.

Analysis of variance was used to determine differences in percentages of seeds found on the soil surface, within the biological limit and below the biological limit in relation to the treatments.

\section{Results and Discussion}

Various interactions of year, species, and seedbed treatment were significant $(P<0.01)$ for depth at which seeds were buried immediately after treatment and after rainfall (Table 1). Seed distribution of all 4 species immediately after treatment showed

Table 1. Repeated measures analysis of variance of depth at which cumulative percentages of broadcast seeds were found for 4 grass species immediately after seedbed treatment and after at least $20 \mathrm{~mm}$ of rain.

\begin{tabular}{|c|c|c|c|c|}
\hline \multirow[b]{2}{*}{ Source } & \multicolumn{4}{|c|}{ F-values } \\
\hline & df & $\begin{array}{l}\text { After } \\
\text { treatment }\end{array}$ & $\begin{array}{l}\text { After } \\
\text { df }\end{array}$ & rain \\
\hline Percentage $\times$ Year & 9 & $3.98 * *$ & 9 & 0.25 \\
\hline Percentage $\times$ Species & 27 & $2.64 * *$ & 27 & $5.97 * *$ \\
\hline Percentage $\times$ Treatment & 27 & $51.15 * *$ & 36 & $6.78 * *$ \\
\hline Percentage $\times$ Year $\times$ Species & 27 & $4.10 * *$ & 27 & 0.91 \\
\hline Percentage $\times$ Year $\times$ Treatment & 27 & $5.81 * *$ & 36 & $2.20 * *$ \\
\hline $\begin{array}{l}\text { Percentage } \times \text { Species } \times \\
\text { Treatment }\end{array}$ & 81 & 1.21 & 108 & 1.18 \\
\hline $\begin{array}{l}\text { Percentage } \times \text { Year } \times \text { Species } \times \\
\text { Treatment }\end{array}$ & 81 & 0.86 & 108 & 1.49 \\
\hline
\end{tabular}

**Significant at the 0.01 level. similar trends between the 2 years, with the exception that seeds from all species were buried deeper by heavy trampling in 1988 (Fig. 1).

Heavy trampling was the most effective treatment in burying sideoats grama seeds, followed by imprinting, light trampling, and no disturbance. Heavy trampling buried seeds to a depth of $27 \mathrm{~mm}$, compared to $17 \mathrm{~mm}$ for imprinting, $16 \mathrm{~mm}$ for light trampling and only $6 \mathrm{~mm}$ for no disturbance.

Blue panic seed burial followed trends similar to sideoats grama burial. However, the smooth, more spherical blue panic seeds were found deeper than grama seeds in the seedbed. Heavy trampling buried seeds to $33 \mathrm{~mm}$, imprinting to $22 \mathrm{~mm}$, light trampling to 11 $\mathrm{mm}$ and no disturbance to $7 \mathrm{~mm}$.

Seeds of the 2 lovegrasses showed similar distribution and depth of seed burial, with the exception that imprinting buried more Lehmann than Chochise lovegrass seeds. Again, heavy trampling buried most seeds, followed by imprinting, light trampling, and no disturbance. Heavy trampling buried seeds of both species to depths of more than $30 \mathrm{~mm}$, followed by imprinting near $20 \mathrm{~mm}$, light trampling near $10 \mathrm{~mm}$, and no disturbance to $7 \mathrm{~mm}$.

Seed location after summer thunderstorms was highly variable between years and among species, but generally thunderstorms increased seed burial. The trend of increased burial with increased seedbed disturbance seen in seed placement after treatment, continued after rainfall. However, in many cases, more seeds in rootplowed or ripped plots were buried than seeds in other treatments. Root plowing or ripping produces a highly fragmented seedbed and natural soil sloughing may help bury seeds.

There was a significant $(P \leq 0.01)$ interaction between depth at which seedlings emerged and species, but not seedbed treatment. This indicates that different species emerged from different depth 

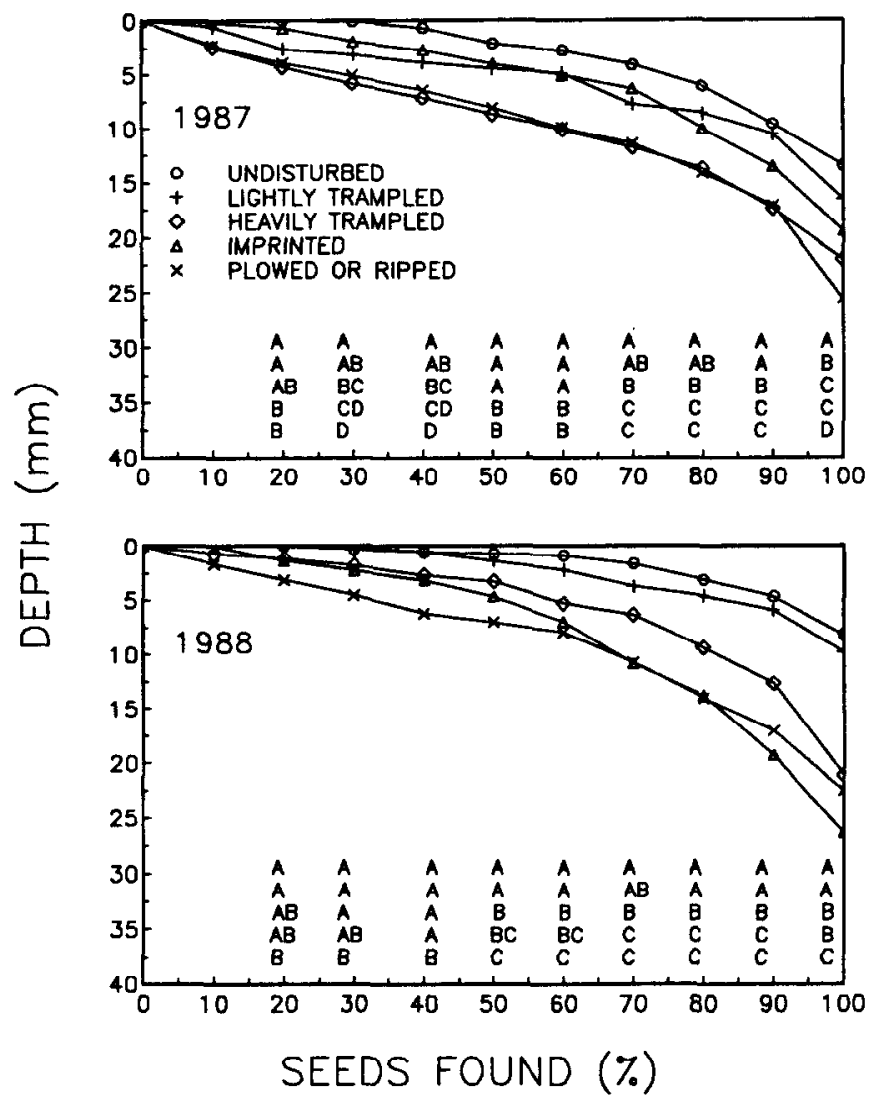

Fig. 2. Vertical distribution of sidecats grama, blue panic, and Cochise and Lehmann lovegrass seeds in a sandy loam soil after summer thunderstorms in relation to seedbed treatment. Columns having the same letter are not significantly different $(P>0.05)$.

intervals, but that each species had similar depth intervals of emergence for all seedbed treatments.

Blue panic seedlings emerged from greater depths than the other 3 species, followed by sideoats grama, then Cochise lovegrass and then Lehmann lovegrass (Fig. 3). All blue panic, sideoats grama, and Cochise and Lehmann lovegrass seedlings emerged from above $18,16,10$, and $9 \mathrm{~mm}$, respectively. Nearly all seedlings from all species emerged from buried seeds, even though after rain, many seeds remained on the soil surface. Either seeds on the surface did not germinate, or many were buried between sampling after rain and seedling emergence. Some seedlings of sideoats grama, blue panic, and Cochise lovegrass emerged from $30 \mathrm{~mm}, 30$ $\mathrm{mm}$, and $20 \mathrm{~mm}$, respectively, in a greenhouse study (Winkel 1990). Differences between these data and the field data may have been a result of higher bulk density in the field or differences in germination conditions.

Seeds of blue panic and sideoats grama emerged from greater depths in the seedbed than the small-seeded lovegrasses, possibly due to greater seed size and more seed reserves. Blue panic seeds are about 1 by $2 \mathrm{~mm}$ and sideoats grama seeds are 1 by $5 \mathrm{~mm}$, compared to seeds of Cochise and Lehmann lovegrass which are about 0.5 by $0.75 \mathrm{~mm}$. The recommended sowing depth for blue panic and sideoats grama is $12 \mathrm{~mm}$ and that for the lovegrasses is 7 $\mathrm{mm}$ (Jordan 1981). The results of this study confirm these recommendations. Based on this study and other observations, we suggest that on coarse-textured soils in southern Arizona, it may be practical to broadcast lovegrass seeds on undisturbed seedbeds. Seeds will then either establish on the surface or be buried after summer thunderstorms.

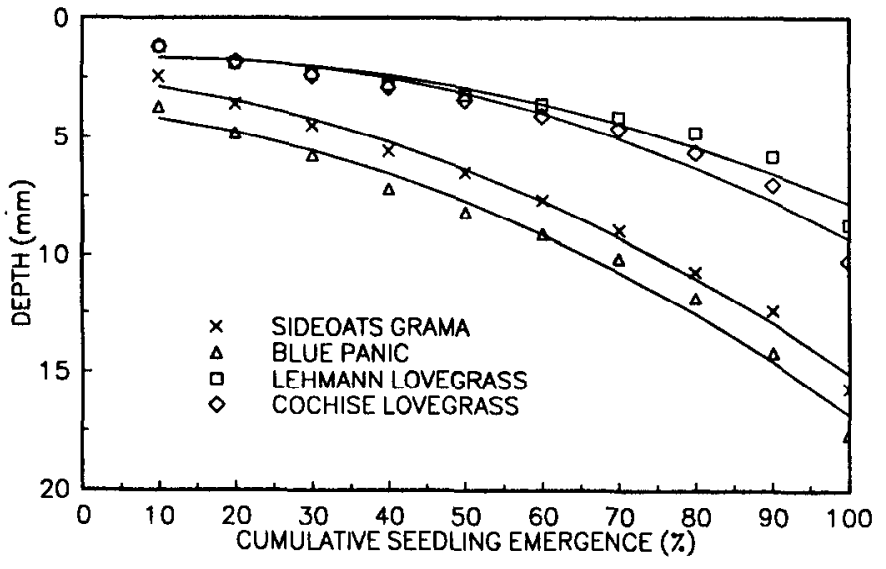

Fig. 3. Cumulative seedling emergence of sideoats grama, blue panic, and Cochise and Lehmann lovegrass in relation to depth in the seedbed on a sandy loam soll.

About $90 \%$ of the seedlings emerged from seeds that were within $6,7,12$, and $14 \mathrm{~mm}$ from the soil surface for Lehmann lovegrass, Cochise lovegrass, sideoats grama, and blue panic respectively (Fig. 3). These depths were considered the biological limit of emergence for these species in this soil. Analyses of variance on percent of seeds found after treatment and after rain on the soil surface, and within and below the biological limit produced 2 and 3 factor interactions of year, species, and treatment (Table 2). In

Table 2. Analysis of variance of percentage of seeds of 4 grass species found in different depth categories in relation to time of sampling and seedbed preparation treatment.

\begin{tabular}{|c|c|c|c|c|}
\hline \multirow[b]{2}{*}{ Source } & \multirow[b]{2}{*}{ df } & \multicolumn{3}{|c|}{ F-values } \\
\hline & & Surface & $\begin{array}{l}\text { Within } \\
\text { biological } \\
\text { limit }\end{array}$ & $\begin{array}{l}\text { Below } \\
\text { biological } \\
\text { limit }\end{array}$ \\
\hline \multicolumn{5}{|l|}{ After treatment } \\
\hline $\begin{array}{l}\text { Year } \\
\text { Species } \\
\text { Treatment } \\
\text { Year } \times \text { Species } \\
\text { Year } \times \text { Treatment } \\
\text { Species } \times \text { Treatment } \\
\text { Year } \times \text { Species } \times \text { Treatment }\end{array}$ & $\begin{array}{l}1 \\
3 \\
3 \\
3 \\
3 \\
9 \\
9\end{array}$ & $\begin{array}{c}0.06 \\
9.38 * * \\
115.45^{* *} \\
0.35 \\
2.08 \\
0.89 \\
1.07\end{array}$ & $\begin{array}{l}1.96 \\
9.57 * * \\
76.68 \\
0.94 \\
11.33 * * \\
3.96 * * \\
1.71\end{array}$ & $\begin{array}{l}1.02 \\
7.15 * * \\
86.71 * * \\
2.14 \\
4.71 * * \\
2.95 * * \\
0.44\end{array}$ \\
\hline \multicolumn{5}{|l|}{ After rain } \\
\hline $\begin{array}{l}\text { Year } \\
\text { Species } \\
\text { Treatment } \\
\text { Year } \times \text { Species } \\
\text { Year } \times \text { Treatment } \\
\text { Species } \times \text { Treatment } \\
\text { Year } \times \text { Species } \times \text { Treatment }\end{array}$ & $\begin{array}{r}1 \\
3 \\
4 \\
3 \\
4 \\
12 \\
12\end{array}$ & $\begin{array}{l}13.34 * * \\
12.52 * * \\
22.16 * * \\
0.19 \\
3.07 * \\
0.80 \\
2.29 *\end{array}$ & $\begin{array}{l}3.81 * \\
3.44 * \\
6.13 * * \\
0.81 \\
1.20 \\
0.66 \\
1.68\end{array}$ & $\begin{array}{c}5.27 * \\
7.67 * \\
17.09 * \\
0.82 \\
2.00 \\
0.78 \\
1.78\end{array}$ \\
\hline
\end{tabular}

significant at the 0.05 level.

**significant at the 0.01 level.

general, greater soil surface disturbance (heavy trampling, land imprinting, and root plowing or ripping) buried more seeds, but also placed more seeds below the biological limit (Table 3).

All species generally responded similarly to the treatments with the exception that fewer sideoats grama seeds were buried than seeds of the other species. This was probably because these seeds were larger, and most were still contained in spikelets. This prevented seeds from being easily sifted through the seedbed. Heavy trampling was the most successful in burying sideoats grama seeds.

Summer thunderstorms (20 $\mathrm{mm}$ of rain in $1987,35 \mathrm{~mm}$ in 1988) 
Table 3. Percent of seeds found on the soil surface, within the biological limit, and below the biological limit in relation to year, sampling time, species and seedbed treatment. 1

\begin{tabular}{|c|c|c|c|c|c|c|c|c|c|c|c|c|}
\hline \multirow[b]{3}{*}{ Species treatment } & \multicolumn{6}{|c|}{1987} & \multicolumn{6}{|c|}{1988} \\
\hline & \multicolumn{3}{|c|}{ Immediately after treatment } & \multicolumn{3}{|c|}{ After rain $(20-\mathrm{mm})$} & \multicolumn{3}{|c|}{ Immediately after treatment } & \multicolumn{3}{|c|}{ After rain (35-mm) } \\
\hline & Surface & $\begin{array}{l}\text { Within } \\
\text { biol. } \\
\text { limit }\end{array}$ & $\begin{array}{l}\text { Below } \\
\text { biol. } \\
\text { limit }\end{array}$ & Surface & $\begin{array}{l}\text { Within } \\
\text { biol. } \\
\text { limit }\end{array}$ & $\begin{array}{l}\text { Below } \\
\text { biol. } \\
\text { limit }\end{array}$ & Surface & $\begin{array}{l}\text { Within } \\
\text { biol. } \\
\text { limit }\end{array}$ & $\begin{array}{l}\text { Below } \\
\text { biol. } \\
\text { limit }\end{array}$ & Surface & $\begin{array}{l}\text { Within } \\
\text { biol. } \\
\text { limit }\end{array}$ & $\begin{array}{l}\text { Below } \\
\text { biol. } \\
\text { limit }\end{array}$ \\
\hline Sideoats grama &.--- & $\ldots \ldots$ & 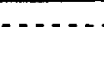 & $-0-0$ & $\ldots$ & $\ldots$ & 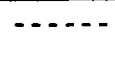 & $-\ldots$ & 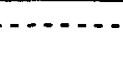 & 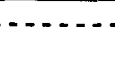 & $-\ldots$ & - \\
\hline $\begin{array}{l}\text { Undisturbed } \\
\text { Light trampling } \\
\text { Heavy trampling } \\
\text { Land imprinting } \\
\text { Root plowing }\end{array}$ & $\begin{array}{c}100.0 \mathrm{a}^{2} \\
98.2 \mathrm{a} \\
25.5 \mathrm{c} \\
77.1 \mathrm{~b} \\
-\end{array}$ & $\begin{array}{r}0.0 \mathrm{c} \\
0.9 \mathrm{c} \\
58.1 \mathrm{a} \\
22.9 \mathrm{~b} \\
-\end{array}$ & $\begin{array}{c}0.0 \mathrm{~b} \\
0.9 \mathrm{~b} \\
16.4 \mathrm{a} \\
0.0 \mathrm{~b} \\
-\end{array}$ & $\begin{array}{l}88.1 \mathrm{a} \\
72.5 \mathrm{ab} \\
8.5 \mathrm{c} \\
75.5 \mathrm{ab} \\
51.4 \mathrm{~b}\end{array}$ & $\begin{array}{l}6.3 \mathrm{c} \\
25.4 \mathrm{bc} \\
68.6 \mathrm{a} \\
14.6 \mathrm{bc} \\
32.2 \mathrm{~b}\end{array}$ & $\begin{array}{c}5.6 \mathrm{ab} \\
2.1 \mathrm{~b} \\
23.0 \mathrm{a} \\
10.0 \mathrm{ab} \\
16.5 \mathrm{ab}\end{array}$ & $\begin{array}{l}95.3 \mathrm{a} \\
88.7 \mathrm{a} \\
42.1 \mathrm{~b} \\
79.9 \mathrm{a} \\
-\end{array}$ & $\begin{array}{c}4.7 \mathrm{c} \\
8.3 \mathrm{bc} \\
26.7 \mathrm{a} \\
17.6 \mathrm{ab} \\
-\end{array}$ & $\begin{array}{c}0.0 \mathrm{~b} \\
3.1 \mathrm{~b} \\
31.3 \mathrm{a} \\
2.6 \mathrm{~b} \\
-\end{array}$ & $\begin{array}{l}81.1 \mathrm{a} \\
79.6 \mathrm{a} \\
75.0 \mathrm{a} \\
67.9 \mathrm{a} \\
27.8 \mathrm{~b}\end{array}$ & $\begin{array}{l}13.3 \mathrm{ab} \\
20.4 \mathrm{ab} \\
15.5 \mathrm{~b} \\
23.3 \mathrm{ab} \\
43.3 \mathrm{a}\end{array}$ & $\begin{array}{l}5.6 \mathrm{~b} \\
0.0 \mathrm{~b} \\
9.5 \mathrm{ab} \\
8.9 \mathrm{ab} \\
28.9 \mathrm{a}\end{array}$ \\
\hline $\begin{array}{l}\text { Blue panic } \\
\text { Undisturbed } \\
\text { Light trampling } \\
\text { Heavy trampling } \\
\text { Land imprinting } \\
\text { Root plowing }\end{array}$ & $\begin{array}{l}97.7 \mathrm{a} \\
70.4 \mathrm{~b} \\
14.4 \mathrm{c} \\
52.9 \mathrm{~b} \\
-\end{array}$ & $\begin{array}{c}2.1 \mathrm{c} \\
29.3 \mathrm{~b} \\
65.7 \mathrm{a} \\
37.7 \mathrm{~b} \\
-\end{array}$ & $\begin{array}{c}0.2 \mathrm{~b} \\
0.3 \mathrm{~b} \\
19.9 \mathrm{a} \\
9.3 \mathrm{a} \\
-\end{array}$ & $\begin{array}{c}36.1 \mathrm{a} \\
38.9 \mathrm{a} \\
3.6 \mathrm{~b} \\
20.5 \mathrm{ab} \\
12.1 \mathrm{ab}\end{array}$ & $\begin{array}{l}42.8 \mathrm{a} \\
34.1 \mathrm{a} \\
56.2 \mathrm{a} \\
58.3 \mathrm{a} \\
44.4 \mathrm{a}\end{array}$ & $\begin{array}{l}21.1 \mathrm{a} \\
27.1 \mathrm{a} \\
40.2 \mathrm{a} \\
21.1 \mathrm{a} \\
43.5 \mathrm{a}\end{array}$ & $\begin{array}{l}93.4 \mathrm{a} \\
91.0 \mathrm{a} \\
15.6 \mathrm{c} \\
57.0 \mathrm{~b} \\
-\end{array}$ & $\begin{array}{r}6.6 \mathrm{~b} \\
9.0 \mathrm{~b} \\
48.8 \mathrm{a} \\
39.8 \mathrm{a} \\
-\end{array}$ & $\begin{array}{r}0.0 \mathrm{~b} \\
0.0 \mathrm{~b} \\
35.7 \mathrm{a} \\
3.2 \mathrm{~b} \\
-\end{array}$ & $\begin{array}{r}84.3 \mathrm{a} \\
66.7 \mathrm{a} \\
22.9 \mathrm{~b} \\
18.8 \mathrm{~b} \\
3.1 \mathrm{~b}\end{array}$ & $\begin{array}{l}15.7 \mathrm{~b} \\
33.3 \mathrm{ab} \\
57.1 \mathrm{a} \\
37.5 \mathrm{ab} \\
25.0 \mathrm{ab}\end{array}$ & $\begin{array}{r}0.0 \mathrm{~b} \\
0.0 \mathrm{~b} \\
20.0 \mathrm{~b} \\
43.8 \mathrm{a} \\
71.9 \mathrm{a}\end{array}$ \\
\hline $\begin{array}{l}\text { Lehmann lovegrass } \\
\text { Undisturbed } \\
\text { Light trampling } \\
\text { Heavy trampling } \\
\text { Land imprinting } \\
\text { Root plowing }\end{array}$ & $\begin{array}{l}90.3 \mathrm{a} \\
78.6 \mathrm{a} \\
26.9 \mathrm{~b} \\
44.9 \mathrm{~b} \\
-\end{array}$ & $\begin{array}{c}9.4 \mathrm{c} \\
21.2 \mathrm{bc} \\
48.9 \mathrm{a} \\
24.5 \mathrm{~b} \\
-\end{array}$ & $\begin{array}{r}0.3 \mathrm{~b} \\
0.1 \mathrm{~b} \\
24.1 \mathrm{a} \\
30.7 \mathrm{a} \\
-\end{array}$ & $\begin{array}{l}78.7 \mathrm{a} \\
59.3 \mathrm{ab} \\
12.3 \mathrm{~b} \\
35.0 \mathrm{~b} \\
6.7 \mathrm{~b}\end{array}$ & $\begin{array}{c}18.4 \mathrm{ab} \\
8.2 \mathrm{~b} \\
46.0 \mathrm{a} \\
38.6 \mathrm{a} \\
35.5 \mathrm{a}\end{array}$ & $\begin{array}{l}2.9 \mathrm{~b} \\
32.5 \mathrm{a} \\
41.7 \mathrm{a} \\
26.4 \mathrm{a} \\
57.9 \mathrm{a}\end{array}$ & $\begin{array}{l}86.6 \mathrm{a} \\
79.1 \mathrm{a} \\
26.6 \mathrm{~b} \\
47.9 \mathrm{~b} \\
-\end{array}$ & $\begin{array}{l}13.4 \mathrm{a} \\
18.1 \mathrm{a} \\
19.9 \mathrm{a} \\
23.7 \mathrm{a} \\
-\end{array}$ & $\begin{array}{c}0.0 \mathrm{c} \\
2.7 \mathrm{c} \\
53.5 \mathrm{a} \\
28.4 \mathrm{~b} \\
-\end{array}$ & $\begin{array}{l}55.6 \mathrm{a} \\
54.5 \mathrm{a} \\
69.3 \mathrm{a} \\
37.5 \mathrm{a} \\
40.8 \mathrm{a}\end{array}$ & $\begin{array}{l}22.2 \mathrm{a} \\
38.8 \mathrm{a} \\
22.1 \mathrm{a} \\
35.0 \mathrm{a} \\
26.0 \mathrm{a}\end{array}$ & $\begin{array}{r}22.2 \mathrm{a} \\
6.8 \mathrm{a} \\
8.6 \mathrm{a} \\
27.5 \mathrm{a} \\
33.2 \mathrm{a}\end{array}$ \\
\hline $\begin{array}{l}\text { Cochise lovegrass } \\
\text { Undisturbed } \\
\text { Light trampling } \\
\text { Heavy trampling } \\
\text { Land imprinting } \\
\text { Root plowing }\end{array}$ & $\begin{array}{l}96.1 \mathrm{a} \\
81.1 \mathrm{a} \\
23.6 \mathrm{~b} \\
44.8 \mathrm{~b} \\
-\end{array}$ & $\begin{array}{r}3.3 \mathrm{c} \\
15.7 \mathrm{~b} \\
43.3 \mathrm{a} \\
35.3 \mathrm{a} \\
-\end{array}$ & $\begin{array}{l}0.5 \mathrm{~b} \\
3.2 \mathrm{~b} \\
33.1 \mathrm{a} \\
20.0 \mathrm{a} \\
-\end{array}$ & $\begin{array}{r}59.0 \mathrm{a} \\
58.1 \mathrm{a} \\
5.6 \mathrm{~b} \\
17.4 \mathrm{~b} \\
6.8 \mathrm{~b}\end{array}$ & $\begin{array}{l}25.1 \mathrm{a} \\
36.1 \mathrm{a} \\
50.1 \mathrm{a} \\
44.0 \mathrm{a} \\
43.5 \mathrm{a}\end{array}$ & $\begin{array}{l}15.9 \mathrm{bc} \\
5.8 \mathrm{c} \\
44.3 \mathrm{ab} \\
38.6 \mathrm{ab} \\
49.7 \mathrm{a}\end{array}$ & $\begin{array}{l}86.0 \mathrm{a} \\
80.4 \mathrm{a} \\
23.5 \mathrm{c} \\
60.9 \mathrm{~b} \\
-\end{array}$ & $\begin{array}{l}13.9 \mathrm{~b} \\
19.4 \mathrm{~b} \\
31.5 \mathrm{a} \\
31.9 \mathrm{a} \\
-\end{array}$ & $\begin{array}{c}0.1 \mathrm{c} \\
0.2 \mathrm{bc} \\
45.0 \mathrm{a} \\
7.2 \mathrm{~b} \\
-\end{array}$ & $\begin{array}{l}81.6 \mathrm{a} \\
52.5 \mathrm{ab} \\
24.4 \mathrm{~b} \\
25.1 \mathrm{~b} \\
28.8 \mathrm{~b}\end{array}$ & $\begin{array}{l}18.2 \mathrm{a} \\
23.7 \mathrm{a} \\
43.7 \mathrm{a} \\
23.6 \mathrm{a} \\
32.4 \mathrm{a}\end{array}$ & $\begin{array}{r}0.2 \mathrm{~b} \\
23.8 \mathrm{a} \\
31.9 \mathrm{a} \\
51.3 \mathrm{a} \\
38.8 \mathrm{a}\end{array}$ \\
\hline
\end{tabular}

${ }_{1}^{1}$ Percent of seeds on the surface, and within and below biological limit may not add to 100 due to rounding of numbers.

${ }^{2}$ Means in a column with a species followed by the same letter are not significantly different $(P>0.05)$.

effectively buried more seeds for all treatments, including no disturbance (Table 3). In fact, after rain, similar percentages of lovegrass and blue panic seeds were buried within and below the biological limit regardless of the treatment. Rain was less effective in burying sideoats grama seeds. Once again, more sideoats grama seeds were buried in the heavily trampled plots.

Greater seedling emergence in heavily disturbed plots in some cases may have been due to greater seed burial by these treatments. On a wet year (1987) there was generally similar emergence of small-seeded lovegrasses among all treatments, but greater seedling emergence of blue panic was associated with greater seedbed disturbance and seed burial by heavy trampling, imprinting, and ripping (Winkel and Roundy 1991b). On a moderately wet year (1988) greater seed ling emergence of all grasses was associated with greater seedbed disturbance and seed burial by heavy trampling, imprinting, and ripping. Since many seeds from less-disturbed plots were still on the surface after rain, the fact that nearly all seedlings sampled after emergence came from buried seeds suggests that seeds remaining on the surface on undisturbed plots did not germinate or were washed away by rain.

All 4 species tested in this study have shallow biological limits. Also, their adventitious roots are initiated from the coleoptilar node, which is nearly always within 1 to $2 \mathrm{~mm}$ of the soil surface. Adventitious root initiation requires 2-4 days of optimal soil water conditions (Olmsted 1942, Wilson and Briske 1979, Winkel 1990). Soil water from the top $3 \mathrm{~cm}$ of soil in this study is depleted from -0.03 to $-0.1 \mathrm{MPa}$ matric potential within 1 to 4 days after a rainstorm (Roundy, unpublished data Univ. of Arizona). Seeds buried deeper within the shallow biological limits of these species probably do not have a significantly longer period of available water than those at a more shallow depth under the rapid drying conditions of the Southwest. A greenhouse study (Winkel 1990). indicated that seedling emergence and primary root lengths of sideoats grama, blue panic, and Cochise lovegrass can decrease with increased planting depth.

decrease with increased planting depth.

Soil disturbance by cattle trampling or mechanical treatments definitely can bury seeds at a desirable depth for emergence. However, summer rains can bury many small seeds even on unprepared seedbeds. Seed burial increases seedling emergence probably by increasing seed-soil contact and water flow to the seed (CollisGeorge and Sands 1959). Seedling emergence of species with shallow biological limits depends on successive storms to maintain available water in the seedbed. Treatments used to help bury seeds would not necessarily be expected to increase seedling emergence of these species in a dry year due to a lack of available water above the biological limit. In a wet year, soil movement associated with rain will bury many small seeds. However, seedbed treatments increase the numbers of seeds buried and increased seed burial before summer rains may help reduce seed predation and thereby increase seedling emergence. Treatments which highly disturb the seedbed, such as heavy trampling, imprinting, rootplow or ripping, may also bury many seeds too deep for emergence. Seedbed treatments are probably more essential to help bury large than smallseeded species broadcast on the soil surface.

\section{Literature Cited}

Allison, D.V., and C.A. Rechenthin. 1956. Root plowing proved best method of brush control in south Texas. J. Range Manage. 9:130-133.

Campbell, M.H., and F.G.Swain. 1973. Factors causing losses during the establishment of surface-sown pastures. J. Range Manage. 26:355-359. 
Clary, W.P. 1988. Plant density and cover response to several seeding techniques following wildfire. Res. Note INT-384, USDA, Forest Service, Intermountain Res. Sta.

Clary, W.P. 1989. Revegetation by land imprinter and rangeland drill. Res. Pap. Int-397. USDA, Forest Service, Intermountain Res. Sta.

Collis-George, N., and J.E. Sands. 1959. The control of seed germination by moisture as a soil physical property. Aust. J. Res. 10:628-636.

Cox, J.R., and M.H. Martin. 1984. Effects of planting depth and soil texture on the emergence of four lovegrasses. J. Range Manage. 37:204-205.

Cox, J.R., M.H. Martin-R., F.A. Ibarra-F., and H.L. Morton. 1936. Establishment of range grasses on various seedbeds at creosotebush (Larrea tridentata) sites in Arizona, U.S.A. and Chihuahua, Mexico. J. Range Manage. 39:540-546.

Haferkamp, M.R., D.C. Ganskopp, R.F. Miller, and F.A. Sneva. 1987. Drilling versus imprinting for establishing crested wheatgrass in the sagebrush-bunchgrass steppe. J. Range Manage. 40:524-530.

Hormay, A.L. 1970. Principles of rest-rotation grazing and multiple-use land management. USDI, Bureau of Land Management. U.S. Government Printing Off., Washington, D.C.

Howard, W.E. 1950. Wildlife depredations on broadcast seedings of burned brushlands. J. Range Manage. 3:291-298.

Jordan, G.L. 1981. Range seeding and brush management on Arizona Rangelands. Bull. T81121, Agr. Exp. Sta., Univ. of Ariz., Tucson.

Morrison, D.F. 1976. Multivariate statistical Methods. 2nd ed. McGrawHill Book Company, New York.

Mutz, J.L., and C.J. Scifres. 1975. Soil texture and planting depth influence bufflegrass emergence. J. Range Manage. 28:222-226.

Nelson, J.R., A.M. Wilson, and C.J. Goebel. 1970. Factors influencing broadcast seeding in bunchgrass range. J. Range Manage. 23:163-169.
Olmsted, C.E. 1942. Growth and development in range grasses. II. Early development of Bouteloua curtipendula as affected by drought periods. Bot. Gazette 103:531-542.

Pearson, C.J., and R.L. Ison. 1987. Agronomy of grassland Systems. Cambridge Univ. Press., Cambridge.

Plummer, P.A., A.C. Hull, Jr., G. Stewart, and J.H. Robertson. 1955. Seeding rangelands in Utah, Nevada, Southern Idaho, and Western Wyoming. USDA, Forest Service, Agr. Handb. 71.

Savory, A. 1978. A holistic approach to ranch management using short duration grazing p. 55-557. In: Proc. 1st Internat. Rangeland Congr. (ed. D.N. Hyder) Soc. Range Manage., Denver, Colo.

Sheldon, J.C. 1974. The behavior of seeds in soil. III. The influence of seed morphology and the behavior of seedlings on the establishment of plants from surface-1ying seeds. J. Ecol. 62:47-66.

Tiedemann, A.R., and E.M. Schmutz. 1966. Shrub control and reseeding effects on the oak chaparral of Arizona. J. Range Manage. 19:191-195.

Vallentine, J.F. 1963. Range seeding in Utah. Ext. Circ. 307. Utah State Univ., Logan.

Vallentine, J.F. 1989. Range development and improvements. Brigham Young Univ. Press, Provo, Utah.

Wilson, A.M., and D.D. Briske. 1979. Seminal and adventitious root growth of blue grama seedlings on the Central Plains. J. Range Manage. 32:209-213.

Winkel, V.K. 1990 . Effects of seedbed modification, sowing depth and soil water on emergence of warm-season grasses. PhD. Diss., University of Arizona, Tucson.

Winkel, V.K., and B.A. Roundy. 1991a. Determination of seed location in relation to seedbed preparation. J. Range Manage.

Winkel, V.K., and B.A. Roundy 1991b. Effects of cattle trampling and mechanical seedbed preparation on grass seedling emergence. J. Range Manage. 44:176-180. 